\title{
MEASUREMENT OF GAS/WATER UPTAKE COEEFICIENTS FOR TRACE GASES ACTIVE IN THE MARINE ENVIRONMENT
}

$\mathrm{DOE} / \mathrm{ER} / 61208--1$

DE92 010033

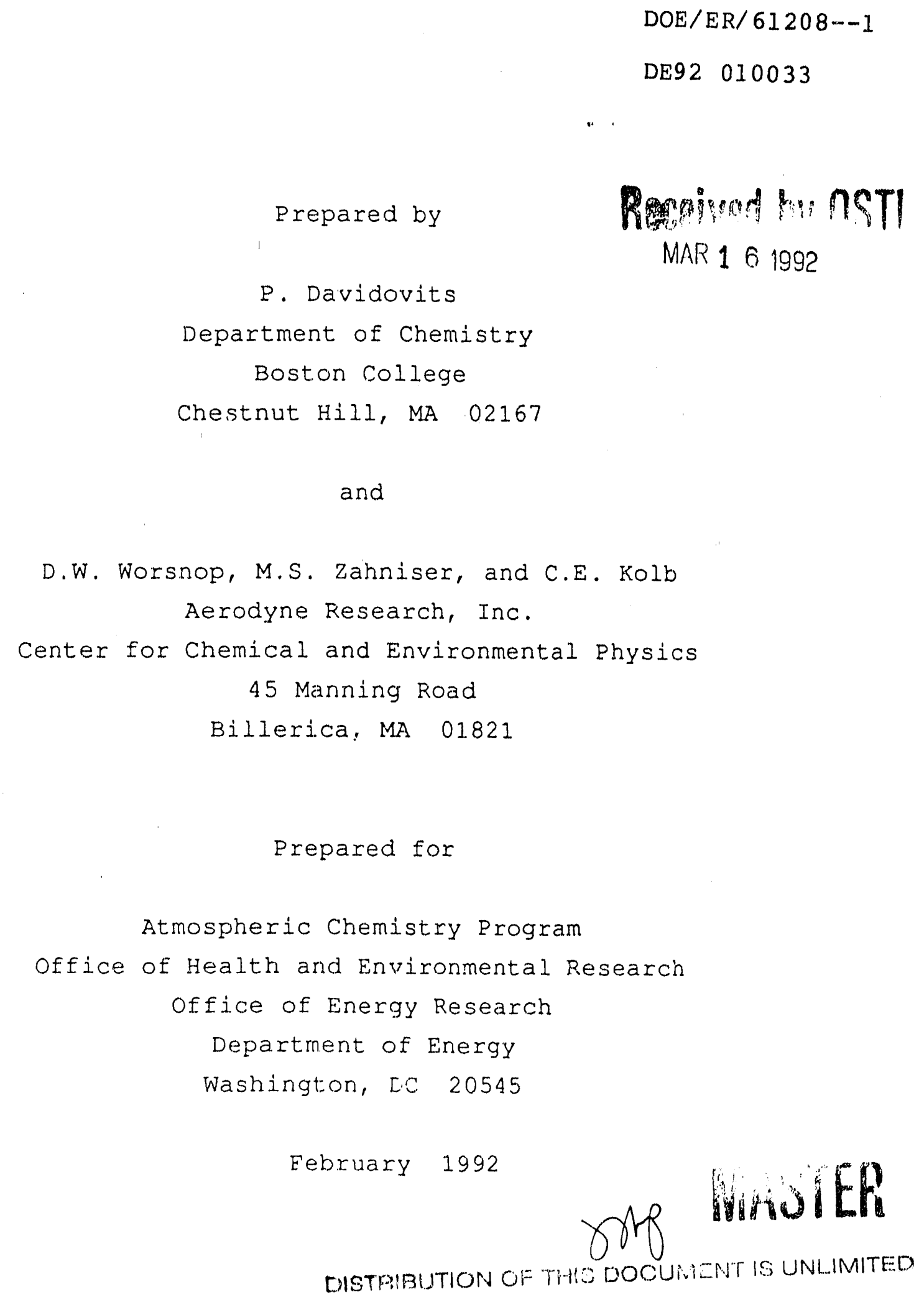




\title{
MEASUREMENT OF GAS/WATER UPTAKE COEFFICIENTS FOR TRACE GASES ACTIVE IN THE MARINE ENVIRONMENT
}

\author{
P. Davidovits, Dept. of Chemistry, Boston College, Chestnut Hill, MA \\ 02167
}

D.W. Worsnop, M.S. Zahniser, and C.E. Kolb, Aerodyne Research, Inc., Center for Chemical and Environmental Physics, 45 Manning Road, Billerica, MA 01821

\begin{abstract}
Ocean produced reduced sulfur compounds including dimethylsufide (DMS), hydrogen sulfide $\left(\mathrm{H}_{2} \mathrm{~S}\right)$, carbon disulfide ( $\left.\mathrm{CS}_{2}\right)$, methyl mercapton ( $\mathrm{CH}_{3} \mathrm{CH}$ ) and carbonyl sulfide (OCS) deliver a sulfur burden to the atmosphere which is roughly equal to sulfur oxides produced by fossil fuel combustion. These species and their oxidation products dimethyl sulfoxide (DMSO), dimethyl sulfone $\left(\mathrm{DMSO}_{2}\right)$ and methane sulfonic acid (MSA) dominate aerosol and $C C N$ production in clean marine air. Furthermore, oxidation of reduced sulfur species will be strongly influenced by $\mathrm{NO}_{\mathrm{X}} / \mathrm{O}_{3}$ chemistry in marine atmospheres. The multiphase chemical processes for these species must be understood in order to study the evolving role of combustion produced sulfur oxides over the oceans.

Unique laboratory techniques developed over the past six years by Boston College and Aerodyne Research, Inc. personnel are being utilized to measure the chemical and physical parameters affecting the uptake of reduced sulfur compounds, their oxidation products, ozone, and nitrogen oxides by the ocean's surface, and marine clouds, fogs, and aerosols. These parameters include: gas/surface mass accommodation coefficients; physical and chemically modified (effective) Henry's law constants; and surface and liquid phase reaction constants. These parameters are critical to understanding both the interaction of gaseous trace species with cloud and fog droplets and the deposition of trace gaseous species to dew covered, fresh water and marine surfaces. Uptake studies are now in progress for MSA and DMSO.
\end{abstract}

\section{DISCLAIMER}

This report was prepared as an account of work sponsored by an agency of the United States Government. Neither the United States Government nor any agency thereof, nor any of their employees, makes any warranty, express or implied, or assumes any legal liability or responsibility for the accuracy, completeness, or usefulness of any information, apparatus, product, or process disclosed, or represents that its use would not infringe privately owned rights. Reference herein to any specific commercial product, process, or sc. vice by trade name, trademark, manufacturer, or otherwise does not necessarily constitute or imply its endorsement, recomrriendation, or favoring by the United States Government or any agency thereoí. The views and opinions of authors expressed herein do not necessarily state or seflect those of the United States Government or any agency thereof. 


\section{TABLE OF CONTENTS}

1. INTRODUCTION

2. TECHNICAL BACKGROUND

3. BOSTON COLLEGE/AERODYNE EXPERIMENTAL PROGRAM

4. EXPERIMENTAL TECHNIQUE

5 REFERENCES

6. PERSONNEL

7. STATEMENT OF WORK

8. PROGRESS REPORT

9. BUDGET 


\section{MEASUREMENT OF GAS/WATER UPTAKE COEFEICIENTS FOR TRACE GASES ACTIVE IN THE MARINE ENVIRONMENT}

P. Davidovits, Dept. of Chemistry, Boston College, Chestnut Hill, MA 02167

D.W. Worsnop, M.S. Zahniser, and C.E. Kolb, Aerodyne Research, Inc., Center for Chemical and Environmental Physics, 45 Manning Road, Billerica, MA 01821

\section{Introduction}

An important task of the Department of Energy Atmospheric Chemistry Program is the study of the atmospheric chemistry and deposition processes associated with long range transport of sulfur and nitrogen oxide species derived from fossil fuel produced $\mathrm{SO}_{2}$ and NOx. Modeling work at the Pacific-Northwest laboratory (PNL) has indicated that long-range transport of sulfur and nitrogen trace species from both North America and Europe can have a major impact on marine air chemistry over the North Atlantic. Furthermore, the accelerated industrial development of Asian nations in the Pacific Basin, particularly China with its low rank coal reserves, can be expected to make major changes in Pacific marine air chemistry.

Changes in marine air chemistry can be of great significance. Atmospheric sulfur and/nitrogen species are critical to the formation of both clear air atrosols and cloud condensation nuclei (CCN). Solar scattering from both clear air aerosols (Ball et al., 1982; Coakley et al., 1983; Charlson et al., 1990) and marine clouds, whose formation is often limited by available CCN, (Coakley, 1987; Charlson et al., 1987) are critical to the atmospheric radiation balance and the climate. The relative role of sulfur oxides produced from reduced sulfur compounds emitted from the ocean and those transported from polluted continental air is currently in dispute (Charlson et al., 1987; Schwartz, 1988).

Ocean produced reduced sulfur compounds including dimethylsulfide (DMS), hydrogen sulfide ( $\left.\mathrm{H}_{2} \mathrm{~S}\right)$, carbon disulfide $\left(\mathrm{CS}_{2}\right)$, methyl mercaptan ( $\mathrm{CH}_{3} \mathrm{SH}$ ) and carbonyl sulfide (OCS) deliver a sulfur burden to the atmosphere which is roughly equal to sulfur oxides produced by fossil fuel combustion (Miller, 1984; Cullis and Hirschler, 1980). These species and their oxidation products dimethyl sulfoxide (DMSO), dimethyl sulfone (DMSO2) and methane sulfonic acid (MSA) dominate aerosol and $C C N$ production in clean marine air. Their multiphase chemical processes must be understood in order to study the evolving role of combustion produced sulfur oxides over the oceans. 
Furthermore, oxidation of reduced sulfur species will be strongly influenced by $\mathrm{NOx} / \mathrm{O}_{3}$ chemistry in marine atmospheres. Therefore it is critical to understand the signs of Nox and $\mathrm{O}_{3}$ in the marine environment. Deposition processes for these species to the ocean surface and into cloud and fog droplets is poorly understood.

The ongoing work in this program element involves the application of advanced laboratory techniques to the measurement of the chemical and physical parameters affecting the uptake of reduced sulfur compounds, their oxidation products, ozone and nitrogen oxides by the ocean's surface, and marine clouds, fogs and aerosols. During the course of this work we anticipate continuing our scientific interface with key DOE ACP scientists involved in cloud and aerosol chemistry in order that our work complement their ongoing activities.

\section{Technical Background}

\section{a). Sulfur species}

There is widespread agreement that DMS is the most important reduced sulfur compound emitted in most marine systems; however, significant emissions of OCS, $\mathrm{CS}_{2}, \mathrm{H}_{2} \mathrm{~S}$ and/or $\mathrm{CH}_{3} \mathrm{SH}$ may be present in some estuarine and marine environment (Andreae, 1985; Aneja, 1990; Pszenny et al., 1989). The oxidation routes for these compounds is poorly understood, with the relative role of gas phase and heterogeneous/liquid phase processes in dispute.

Seinfeld and co-workers have recently published and tested and extensive mechanism for DMS gas phase photo-oxidation which is in reasonable accord with smog chamber simulations ( $Y$ in et al., $1990 a, b)$, but oxidation routes in relatively clean marine air are less certain, and the relative role of homogeneous and heterogeneous reactions for the initial and intermediate oxidation products of DMS and other reduced sulfur compounds is unclear. For instance gas phase reactions with $\mathrm{OH}, \mathrm{Cl}, \mathrm{O}_{3}$ and $\mathrm{NH}_{3}$ are all too slow to explain the atmospheric lifetime of dimethyl sulfate (Japar et al., 1990). A suggested sulfur budget for the antarctic marine boundary layers is shown in Figure 1 (Pszenny et al., 1989). Budgets for other marine systems are similar in form.

Marine aerosol sampling studies show that the important terminal reduced sulfur compound oxidation products include both sulfate $\left(\mathrm{SO}_{4}=\right.$ ) presumably from sulfuric acid and methanesulfonate $\left(\mathrm{CH}_{3} \mathrm{SO}_{3}^{-}\right)$from methanesulfonic acid. Under marine conditions methanesulfonic acid is one of the principle oxidation products of atmospheric DMS. It is quantitatively significant in the atmospheric sulfur budget of oceanic regions, comprising from 5\% to as much as $40 \%$ of the aerosol sulfur in marine air masses. While the atmospheric concentrations of MSA are reasonably well known over the oceans (Saltzman et al., 1983; 1985; 1986), we know relatively 
little about the processes by which MSA is removed from the atmosphere. Hence, our ability to calculate fluxes from atmospheric concentrations is limited.

A question of particular importance is whether the removal rate of MSA is similar to that on non seasalt sulfate, as MSA is used as a tracer for biogenic sulfate both in air masses and in ice cores (Saltzman et al., 1986; Prospero and Savoie, 1989; Saigne and Legrand, 1987, Legrand et a $1 ., 1990)$. This has generally been assumed to be the case on the basis of the similarity in the size distributions of the two compounds. Recent measurements in the equatorial pacific indicate that in very remote marine air masses the size distribution of MSA appears significantly shifted towards coarser particles ( $>1$ micron) relative to nss sulfate (Pszenny, 1990). This observation suggests that MSA is incorporated into the aerosol via nucleation onto preexisting particles, since most of the surface area in the aerosol is on the larger particles. This mechanism was suggested on theoretical grounds by Hoppel (1987) and Kreidenweis and Seinfeld (1988). However, even after taking surface area and particle diffusivity into account, the field data shows that MSA appears to be preferentially adsorbed onto seasalt, rather than sulfuric acid aerosols. Pszenny suggested that this may result from a dependence of the sticking coefficient of MSA. Interestingly, this interpretation of the field data appears to conflict with earlier measurements of the vapor pressure of MSA (Clegg and Brimblecombe, 1985) which indicated that MSA should not volatilize from atmospheric solutions even if they are extremely acidic. Experimental work is needed to verify the vapor pressure data and to determine the sticking coefficient as a function of solution composition.

It is clear that laboratory studies of the interaction of reduced marine sulfur compounds and their oxidation products with liquid water droplets representative of marine cloud, fog and aerosol droplets should provide valuable insights into the processes represented in Figure 1 .

\section{b). Ozone and $\mathrm{NO}_{x}$}

The oxidation of reduced marine sulfur compounds is driven by their interaction with the photochemical oxidation cycle involving NOx, $\mathrm{O}_{3}$ and the $\mathrm{OH}$ radical. For instance the seinfeld group's DMS oxidation model indicates that reaction with $\mathrm{OH}$ and $\mathrm{NO}_{3}$ are the principle pathways for initial oxidation (Yin, et al., 1990a and 1.990b).

NOx and $\mathrm{O}_{3}$ concentrations can be quite low in clear marine air, particularly when compared to polluted continental air. Thus, any loss terms, particularly to cloud or aerosols droplets or the ocean surface must be fully characterized.

The Boston College/Aerodyne (BC/ARI) team has already measured and purlished temperature dependent uptake parameters for the 
important NOx reservoir species $\mathrm{N}_{2} \mathrm{O}_{5}$ and $\mathrm{HNO}_{3}$ (VanDoren et al., 1990). In order to more fully characterize possible marine heterogeneous sinks we propose to extend these studies to $\mathrm{O}_{3}$, No, $\mathrm{NO}_{2}$ and $\mathrm{NO}_{3}$. The uptake of $\mathrm{O}_{3}$ and $\mathrm{NO}_{2}$ by aqueous surfaces has already been studied by BNL sclentists (Tang and Lee, 1987; Lee and Tang, 1988) who measured quite small mass accommodation coefficients of $5.3 \times 10^{-4}$ and $6.2 \times 10^{-4}$, respectively. Since the physical Henry's law constant for these species is small, a chemical scavenging species must be added to measure a true mass accommodation coefficient. The technique used at BNL is not as versatile as the $A R I / B C$ technique and is subject to saturation effects. Differences between the two approaches are indicated by the BNL mass accommodation coefficient of $>2 \times 10^{-2}$ for $\mathrm{SO}_{2}$ (Tang and Lee, 1987) as compared to our value of 0.11 (Worsnop et al., 1989).

In preliminary experiments we have strong indications that the mass accommodation coefficient for $\mathrm{O}_{3}$ significantly exceeds that measured at BNL, particularly when we use $\mathrm{I}^{-}$as an $\mathrm{O}_{3}$ chemical. scavenger. Since $I^{-}$and the other halides are important constituents of sea water and marine aerosol, we feel it is important to more fully explore the uptake of $\mathrm{O}_{3}$ by water surfaces doped with halogen anions.

In general, we would like to check the previous BNL accommodation coefficient measurements for $\mathrm{NO}_{2}$ and $\mathrm{O}_{3}$, with what we feel is a more robust experimental technique, and then go on to explore, in detail, how the chemical composition of ocean water and marine cloud and aerosol drops may govern uptake of gaseous $\mathrm{O}_{3}$ and Nox through reactive scaveriging.

\section{Boston College/Aerodyne Experimental Program}

Over the past five years in a collaborative effort between the Chemistry Department at Boston College (BC) and the Center for Chemical ana Environmental Physics at Aerodyne Research, Inc. (ARI), we have developed a novel and powerful method of measuring mass accommodation coefficients for trace atmospheric species on water droplets of known size, temperature and chemical composition. A controllable stream of monodispersed droplets is produced by a vibrating orifice jet. The droplets enter a flow system containing the trace species. The droplets are turned on and off while the density of the species is monitored Furthermore, through the determination of trace gas uptake rates our experimental techniques have allowed us to determine effective Henry's law solubilities as a function of droplet chemistry. These in turn can be interpreted to yield valuable insight into the rate of trace species chemical reactions at the droplet surface.

In experiments thus far we have measured the mass accommodation coefficients for $\mathrm{SO}_{2}, \mathrm{H}_{2} \mathrm{O}_{2}, \mathrm{~N}_{2} \mathrm{O}_{5}, \mathrm{HNO}_{3}, \mathrm{HCL}, \mathrm{CHOOH}$, $\mathrm{C}_{2} \mathrm{H}_{4} \mathrm{OOH}$, and a series of alkyl-and halo-alcohols under various atmospherically significant conditions. For $\mathrm{HCl}_{1} \mathrm{HNO}_{3}$ and $\mathrm{N}_{2} \mathrm{O}_{5}$, gas 
uptake was also measured as a function of sulfuric acid concentration in the droplets. We have determined the temperature dependence of the uptake for these molecules in the range $-13 \mathrm{C}$ to $20 \mathrm{C}$. These studies show that the mass accommodation coefficients for soluble gases on aqueous surfaces are large ranging from about 0.02 to 0.15 at room temperature. The coefficients generally increase with decreasing temperature. The results suggest that uptake for soluble species proceeds via an attractive gas/surface interaction that may be described in terms of critical cluster size, homogeneous nucleation theory.

The uptake coefficients for less soluble gases are determined by the Henry's law solubility, liquid phase diffusion, and aqueous phase chemical reaction. Detailed studies of $\mathrm{SO}_{2}(\mathrm{~g})$ uptake show that $\mathrm{SO}_{2}$ reacts with $\mathrm{H}_{2} \mathrm{O}$ much more rapidly at the surface of the liquid than in the bulk. Eurther, in the process of uptake a chemisorbed $\mathrm{SO}_{2}-\mathrm{H}_{2} \mathrm{O}$ surface complex is form have significant effect on droplet chemistry. For a typical 10 micron cloud droplet of $\mathrm{pH} 4$ in equilibrium with gas phase $\mathrm{SO}_{2}$, about 30 percent of $S$ (IV) is calculated to be in the surface complex. More recent results indicate that acetaldehyde also chemj.sorbs on the liquid surface, perhaps explaining anomalously high acetaldehyde concentrations reported for collected fog and clold water.

\section{Experimental Technique}

The mass transfer rate between gas and liquid is a convolution of at least three processes: diffusion and/or convection of gas phase molecules to and from the liquid surface, dissolution of gas phase molecules into the liquid (this may include possible chemical reaction at the surface), and the diffusion of dissolved molecules to and from the liquid surface. The goal of any mass accommodation or desorption coefficient measurement is to isolate the heterogeneous surface transport from the gas and liquid transport processes. With this is mind we have two apparatuses in operation to measure these coefficients. One apparatus uses infrared absorption of a tunable diode laser for trace detection while the other uses a mass spectrometer. The apparatus can also be used to study gas desorption, surface chemistry and the temperature dependence of gas uptake. Details of the devices are described in our previous publications (Gardner et al., 1987, Worsnop et al., 1989, Jayne et al., 1990). Extensive tests and experiments discussed in the publications show that the method indeed provides reliable results. In previous publications as well as in our original proposal to DOE, we have described in detail our laboratory technique . Here we will provide only a brief summary of the experimental method.

The mass spectrometer version of our apparatus, shown in Figures 2. The gas / droplet interaction zone consists of a droplet source chamber, a gas-droplet interaction flow tube, and a droplet 
collection chamber. Droplets are generated in the upper chamber by forcing filtered water through a 60 micron diameter orffice in a stainless steel plate. The formation of droplets is controlled by vibrating the orifice with a piezo-electric ceramic at the natural jet breakup frequency or at an integral subharmonic. Droplet sizes from 120 to $240 \mathrm{microns}$ are generated in these experiments by varying the applied frequency. The actual droplet frequency is measured by passing a tightly focused helium neon laser beam through the droplet stream and monitoring the modulated light with a phototube and oscilloscope.

The density $\left(n_{g}\right)$ of the trace gas is monitored as the surface area of the droplets passing through the flow tube is changed in a stepwise fashion. The density of the species is monttored downstream of the flow tube with the quadrupole mass spectrometer (or a diode laser absorption cell). A measured decrease in the trace gas signal $\left(\Delta \mathrm{n}_{\mathrm{g}}\right)$ resulting from an increase in the exposed droplet surface area corresponds to an uptake of the gas by the droplet surface. The uptake coefficient is obtained from the measured change in trace gas signal.

An important aspect of the experimental technique is the careful control of all the conditions within the apparatus. The control of the water vapor pressure is especially important because the temperature of the droplets is determined by the partial pressure of $\mathrm{H}_{2} \mathrm{O}$ vapor in both the droplet generation chamber and the flow tube. The equilibrium between ambient water vapor and the droplet train temperature is reached in the droplet production chamber. The attainment of droplet temperature equilibrium is predicted theoretically and has been checked experimentally. Careful control of the pressure ensures that the droplets neither grow nor evaporate in the reaction zone. Experiments have been done with the pressure of $\mathrm{H}_{2} \mathrm{O}$ in the reaction zone between 13 and 1.7 Torr. This corresponds to temperatures between $15 \mathrm{C}$ and $-13 \mathrm{C}$, respectively. The lower temperatures are obtained by evaporative cooling; the droplets being super-cooled but not frozen

The transit time of the droplets through the reaction zone is short, on the order of a few miliseconds. The gas-droplet interaction time can be varied from 1.8 to $21 \mathrm{~ms}$ by changing the gas inlet port and by altering the droplet velocity. These two methods of varying the contact time were shown to be equivalent. The various factors entering into the analysis of the results have been discussed in previous publications (Worsnop 1989). The apparatus is easily modified to perform quantitative desorption studies. 


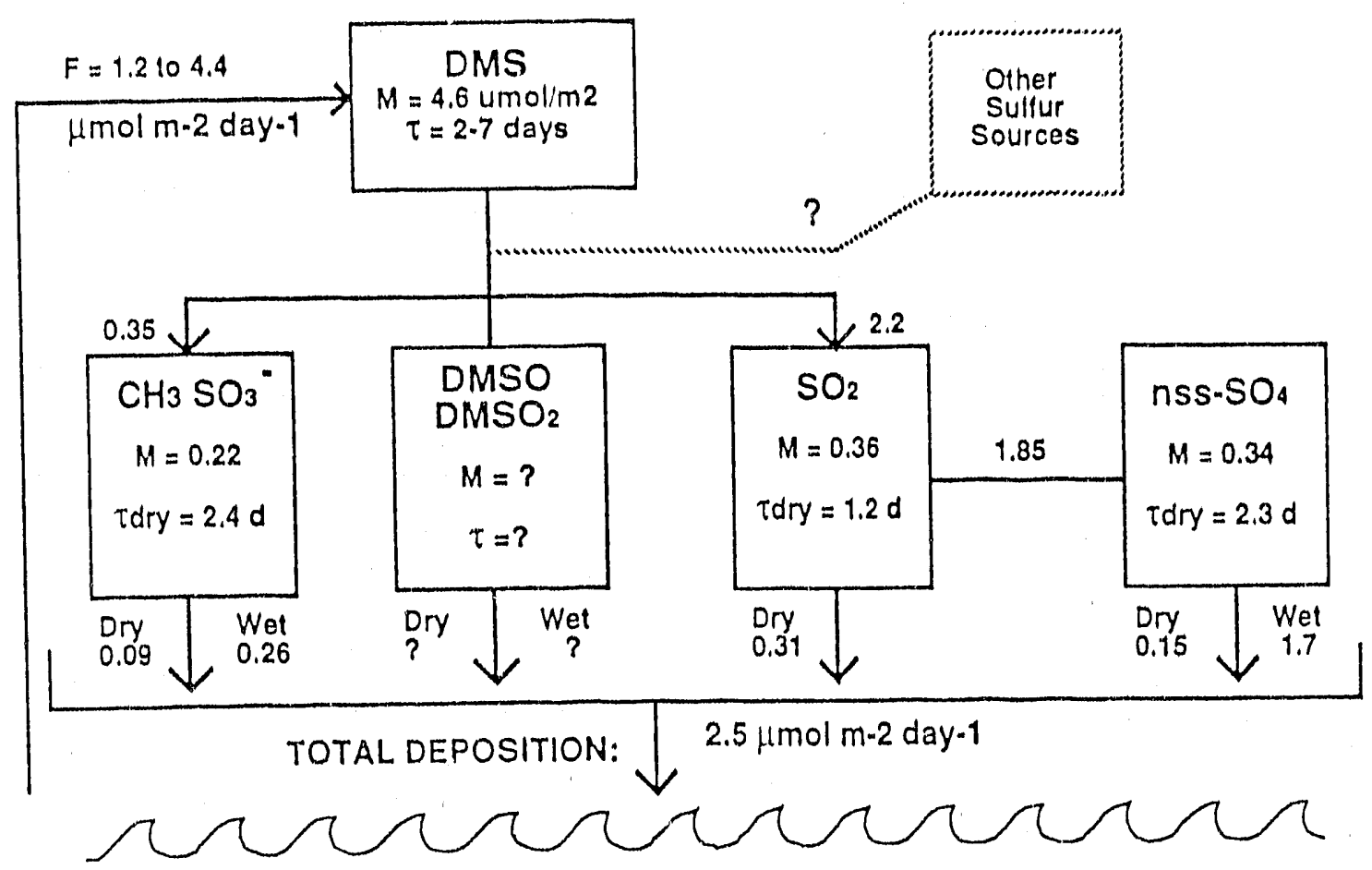

Figure 1. Proposed Sulfur Budget for the Antarctic Marine Boundary Layer. $F, M$. and $t$ are $f l u x$ (in mol $\mathrm{m}^{-2} \mathrm{day}^{-1}$ ), 1000-m column-integrated concentration (in $\mu$ mol $\mathrm{m}^{-2}$ ), and estimated residence time (in days), respectively (Ref. pszenny et al., 1989).

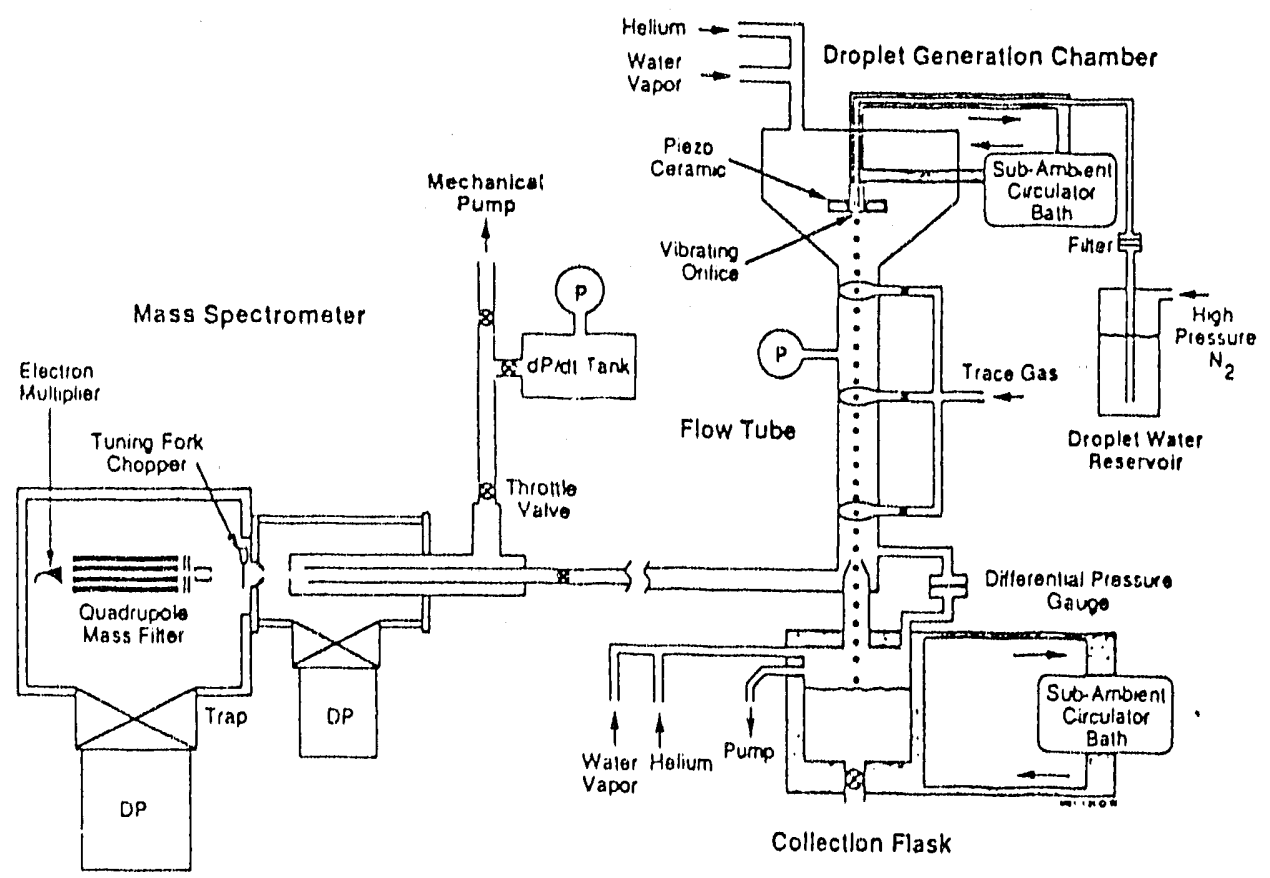

Figure 2 Flow Apparatus with Mass spectrometer. 


\section{References}

Ahrens, M.L., G. Maass, P. Schuster, and H. Winkler, J. Am. Chem. Soc. 92, 6134, 1970 .

Andreae, M.O., The Emission of Sulfur to the Remote Atmosphere: Background Paper, in The Blogeochemical Cycling of Sulfur and Nitrogen in the Remote Atmosphere, J.N. Galloway, Ed., 5-25, 1985.

Aneja, V.P., Natural Sulfur Emissions into the Atmosphere, J.^Air Waste Manage. Assoc. 40,469-476, 1990.

Ball, R.J. and G.D. Robinson, "The Origin of Haze in the central United States and Its Effect on Solar Irradiation," J.^App.

Meteorol. 21, 171-188, 1982 .

Bel1, R.P., Adv. Phys. Org. Chem. 4, 1-29, 1966.

Betterton, E.A. and M.R. Hoffmann, "Henry's Law Constants of Some Environmentally Important Aldehydes, "Env. Sci. Technol 22, 14151418, 1988.

Boyce, S.D. and M.R. Hoffmann, "Kinetics and Mechanism of the Formation of Hydroxymethanesulfonic Acld at Low pH," J. Phys. Chem. 884740,1984 .

Bruins, H.R., "Coefficients of Diffusion in Liquids" in International Critical Tables, Vol. 5, (McGraw Hill, New York, 1929)

Charlson, R.J., J. Langner, and H. Rodhe, "Sulphate Aerosol and Climate," Nature, 348, 22, 1990.

Charlson, R.J., J.E. Lovelock, M.O. Andrae, and S.G. Warren, "Oceanic Phytoplankton, Atmospheric Sulfur, Cloud Albedo, and Climate," Nature 326, 655-661, 1987.

Coakley, J.A., Jr., R.I. Bernstein, and P.A. Durkee, "Effect of Ship-Stack Effluents on Cloud Refelectivity," Science 237, 10201022, 1987.

Coakley, J.A., Jr., R.D. Cress, and F.B. Yurevich, "The Effect of Tropospheric Aerosols on the Earth's Radiation Budget: A Parameterization of C.limate Models," J. Atmos. Sci.40, 116-138, 1983.

Cullis, C.F., and Hirschler, M.M. "Atmospheric Sulfur: Natural and Man-made Sources," Atmos. Environ. 14, 1263-1278, 1980.

Gardner, J.A., L.R. Watson, Y.G. Adewuyi, P. Davidovits, M.S. Zahniser, D.R. Worsnop and C.E. Kolb, "Measurement of the Mass Accommodation Coefficient of $\mathrm{SO}_{2}(\mathrm{~g})$ on Water Droplets," $\mathrm{J}$. Geophys. Res. 92, 10887, 1987. 
Hoppel, W.A. Nucleation in the MSA-Water Vapor System, Atmos. Environ. 21, 2703-2709, 1987.

Igawa, M., J.W. Munger, and M.R. Hoffman, "Analysis of Aldehydes in Cloud-and Fogwater Samples by HPLC with a Postcolumn Reaction Detector," Environ. Sci. Technol. 23, 556-561, 1989.

Jacob, D.J., "Chemistry of $O H$ in Remote Clouds and Its Role in the Production of Formic Acld and Peroxymonosulfate," J. Geophys. Res. 91, 9807, 1986.

Japar, S.M., T.J. Wallington, J.M. Andino and J.C. Ball, Atmospheric Reactivity of Gaseous Dimethyl Sulfate, Environ. Sci. Techno1. 24, 313,1990 .

Jayne, J.T., P. Davidovits, D.R. Worsnop, M.S. Zahniser and C.E. Kolb, "Uptake of $\mathrm{SO} 2(\mathrm{~g})$ by Aqueous Surfaces as a Function of $\mathrm{pH}$ : The Effect of Chemical Reaction at the Interface," J. Phys. Chem. 94, 6041 (1990).

Kreidenweis, S.M. and J.H. Seinfeld, Nucleation of Sulfurlc Actd Water and Methanesulfonic Acid-Water Solution Particles:

Implications for the Atmosphertc Chemistry of Organosulfur species, Atmos. Environ. 22, 283-296, 1988.

Laidler, K., Physical Chemistry, (Benjamin Cummings, Menlo park, 1982), p.^824.

Lee, J.-H. and I.N. Tang, Accommodation Coefficlent of Gaseous NO2 on Water Surfaces, Atmos. Environ. 22, 1147-1151, 1988.

Legrand, M., C. Feniet-Saigne, E.S. Saltzman, C. Germain, N.I. Barkov, and V.N. Petrov, "An Ice-core Record of Oceanic Emission of Dimethylsulfide During the Last Climatic Cycle, Nature, in press, 1990.

Longsworth, L.G. "Diffusion in Liquids" in American Institute of Physics Handbook, 3rd Edition, (McGraw Hill, New York, 1972) pp. $221-229$.

Meier, U., H.H. Grotheer and Th. Just, Chem. Phys. Lett. 106, 97, 1984 .

Miller, D., "Estimation of the Global Man-made Sulphur Emission," Atmos. Environ. 18, 19-27, 1984.

Olson, T.M. and M.R. Hoffman, "Hyaroxyalkylsulfonate Formation: Its Role as A S(IV) Reservoir in Atmospheric Water Droplets," Atmos. Environ. 23, 985-997, 1989.

Pandis, S.N. and J.H. Seinfeld, "Sensitivity Analysis of a Chemical Mechanism for Aqueous-Phase Atmospheric Chemistry," J. Geophys. Res. 94, 1105-1126, 1989. 
Pszenny, A.A., A.J. Castelle, J.N. Galloway and R.A. Duce, A study of the Sulfur Cycle in the Antarctic Marine Boundary Layer, $J$. Geophys. Res. 94, 9818-9830, 1989.

Pszenny, A.A., "Particle Size Distribution of Methane Sulfate in the Tropical Pacific Marine Boundary Layer," submitted to J.^Atmos. Chem., 1990.

Saigne, $C$. and M. Legrand, Measurements of Methanesulfonic Acid in Anarctic Ice, Nature 330, 240-242, 1987.

Saltzman, E.S., D.I. Savoie, J.M. Prospero, and R.G. Zika.

Atmospheric Methanesulfonic Acid and Non-Sea-Salt Sulfate at Fanning and American Samoa, Geophys. Res. Lett., 12, 437-440, 1.985.

Saltzman, E.S., D.I. Savoie, J.M. Prospero, and R.G. Zika. Methane Sulfonic Acid and Non-Sea-Salt Sulfate in the Pacific ocean;

Regional and Seasonal Variations, J. Atmos. Chem., 4, 227-240, 1986.

Saltzman, E.S., D.L. Savoie, R.G. Zika, and J.M. Prospero, Methane Sulfonic Acid in the Marine Atmosphere, J. Geophys. Res. 88, 10897$10902,1383$.

Sivoie, D.L. and J.M. Prospero, Comparison of Oceanic and Conential Sources of Non-Sea-Salt Sulphate Over the Pacific Ocean, Nature 339, $685-689,1989$.

Schecker, H.Gg. and G. Schulz, Zeit. fur Physik. Chemie 65221 , 1969.

Schwartz, S.E., "Chemistry of Multiphase Atmospheric Systems," NATO A.SI Series (W. Jaeschke, ed., Springer-Verlag, Berlin, 1986)

Vol.^G6, P. 415.

Schwartz, S.E., "Are Globai Cloud Albedo and Climate Controlled by Marine Prytoplankton?", Nature 336, $141-445,1988$.

Seigneur, C. and A.M. Wegrecki, "Mathematic Modeling of Cloud Chemistry in the Los Angeles Basic," Atmos. Environ. 24A, 989$1006,1989$.

Snider, J.R. and G.A. Dawson, "Tropospheric Light Alcohols, Carbonyls, and United States and Acetonitrile: Concentrations in the Southwestern $3797-3805,1985$.

Tang, I.N. and J.-H. Lee, Accommodation Coefficient of ozone and S02: Implications on 502 Oxidation in Cloud Water, in The Chemistry of Acid Rain, ACS Sym. Series (R.W. Johnson and G.E. Gordon, eds.) $109-117,1987$.

VanDoren, J.M. I.R. Watson, P. Davidovits, D.R. Worsnop, M.S. Zahniser and C.E. Kolb, J. Phys. Chem. 94, 3264-3269, 1990. 
Viney, A.P., "Natural Sulfur Emissions into the Atmosphere," J. Air Waste Manag. Assoc. 40, 469, 1990.

Worsnop, D.R., M.S. Zahniser, C.E. Kolb, J.A. Gardner, I.R. Watson, J.M. VanDoren, J.T. Jayne and P. Davidovits, "Temperature Dependence of Mass Accommodation of $\mathrm{SO}_{2}$ and $\mathrm{H}_{2} \mathrm{O}_{2}$ on Aqueous surfaces," J. Phys. Chem. 93, 1159, 1989.

Yin, F., D. Grosjean and J.H. Seinfeld, Photooxidation of Dimethyl Sulfide and Dimethyl Dissulfide. I: Mechanism Development, J. Atmos. Chem. 11, 309-364, 1990a.

Y.in, E., D. Grosjean R.C. Elagan and J.H. Seinfeld, Photooxidation of Dimethyl Sulfide and DimethyI Dissulfide. II: Mechanism Development, J. Atmos. Chem. 11, 365-399, 1990b.

\section{Personnel}

\section{Boston College Department of Chemistry \\ Chestnut Hill MA 02167-3860 \\ 617-552-3617 Fax 617-553-2705 \\ Electronic Mail DAVIDOVI@BCVM;}

Paul Davidovits

Su-Xiang Duan

Jianghong Hu

Warren DeBruyn
Erincipal Investigator

Research Associate

Graduate student

Graduate Student

Aerodyne Research Inc.

Billerica, MA 01821

508-663-9500 Fax 508-663-4918

Douglas R. Worsnop

Co-Principal Investigator

Mark S. Zahniser

Co-Principal Investigator

Charles E. Kolb

Co-Principal. Investigator

The principal investigator spends approximately $20 \%$ of his time on this project

\section{The Original statement of work}


The experimental protocols and data analysis procedures described are capable of determining the parameters needed to model heterogeneous chemistry of trace gases on atmospheric particles. These parameters include mass accommodation coefficients, aqueous solubilities, and aqueous reaction kinetics. In order to assess the impact on the marine environment of fossil fuel produced sulfur and nitrogen oxides, we propose to extend our laboratory experiments to those species. This involves the following tasks:

1. Measurements of uptake coefficients on aqueous droplets for the reduced sulfur species including dimethyl sulfide (DMS), hydrogen sulfide $\left(\mathrm{H}_{2} \mathrm{~S}\right)$, carbon disulfide $\left(\mathrm{CS}_{2}\right)$, methyl mercaptan ( $\mathrm{CH} 3 \mathrm{SH}$ ) and their oxidation products including carbonyl sulfide (OCS), methane sulfonic acid (MSA), dimethyl sulfoxide (DMSO) and dimethyl sulfone $\mathrm{DMSO}_{2}$. The uptake coefficients will be measured over a sufficient range of conditions to provide both the mass accommodation coefficient and the Henry's law solubility for these species. Measurements will be done as a function of temperature, $\mathrm{pH}$, and ionic strength.

2 Measurements of uptake coefficients on aqueous droplets for the ozone $\left(\mathrm{O}_{3}\right)$ and the nitrogen oxide species $\mathrm{NO}, \mathrm{NO}_{2}$ and $\mathrm{NO}_{3}$. The uptake coefficients will be measured over a sufficient range of conditions to provide both the mass accommodation coefficient and the Henry's law solubility for these species. Measurements will be done as a function of temperature, $\mathrm{pH}$, and ionic strength.

\section{Progress Report}

During the summer of 1991 the Chemistry Department moved from its old quarters into a new building totally dedicated to teaching and research in chemistry. Being in this new building which is very well equipped with the most modern and advanced research equipment.will no doubt greatly facilitate research. The move however necessitated the disassembling and reassembling of the apparatus which caused some delays in our research program.

The apparatus has now been properly modified to study the compounds relevant to the present project. We have started to measure the uptake of MSA and DMSO. Preliminary measurements show that the uptake coefficient of DMSO by $\mathrm{pH} 7$ water is small; less then $5 \times 10^{-4}$. Further studies as a function of various additives are now in progress. Studies are proceeding as outlined in the work statement. 

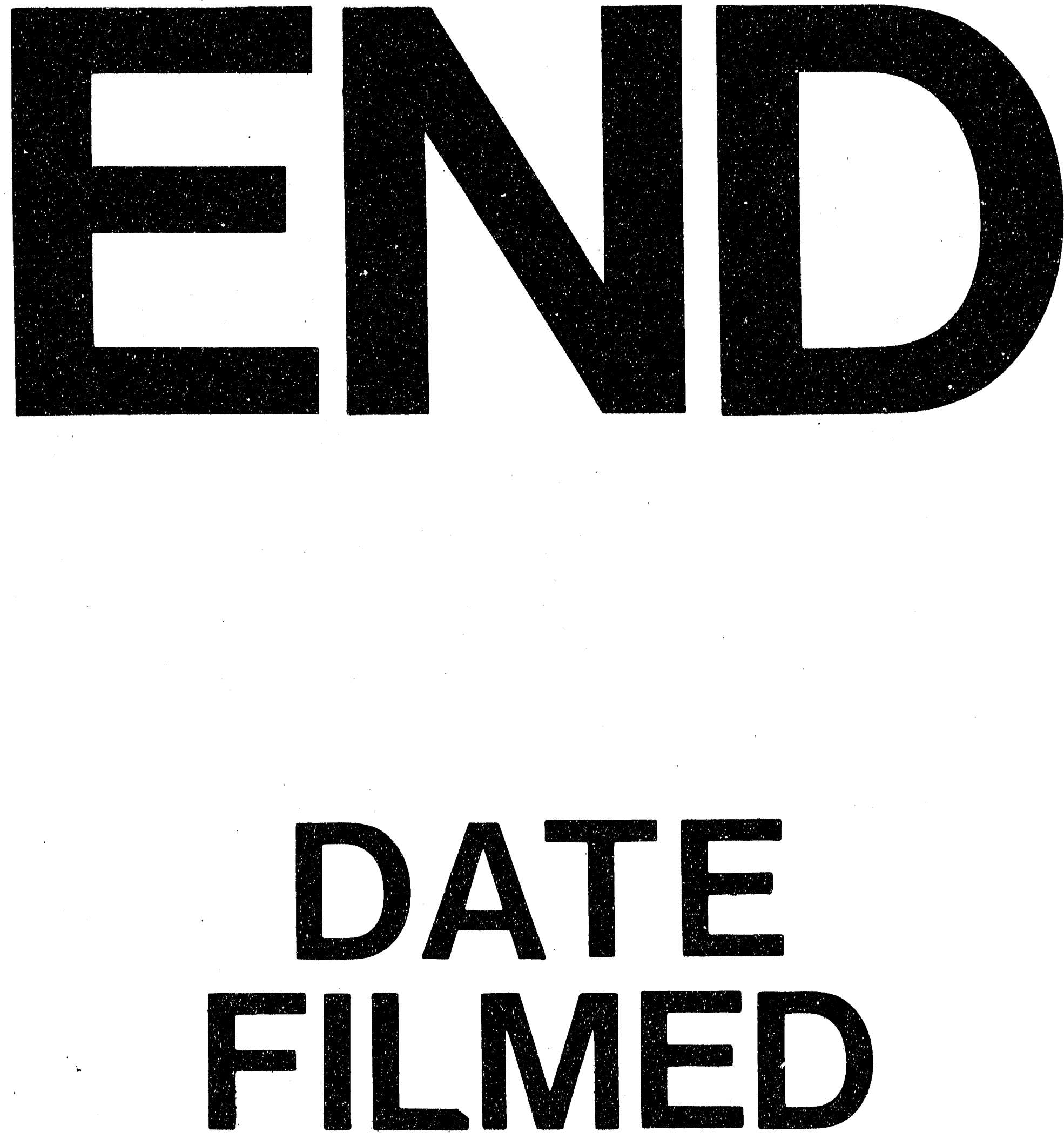

1

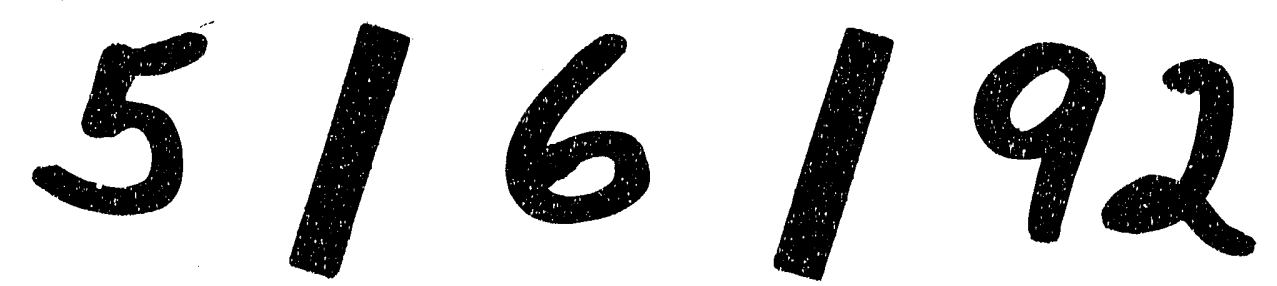




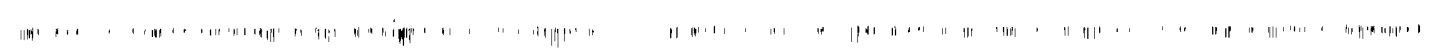

